\title{
Language Choice and Level of Threatened with Extinction at Siladang Language
}

\author{
Syahnan Daulay ${ }^{1,5}$, Amrin Saragih ${ }^{2}$, Tengku Silvana Sinar ${ }^{3}$, Sahron Lubis $^{4}$ \\ ${ }^{1}$ Doctoral Program in Linguistics Department, North Sumatera University, Medan, Indonesia \\ ${ }^{2}$ Faculty of Language, Department of English Language, State University of Medan/Unimed, Medan, Indonesia \\ ${ }^{3}$ Department of Postgraduate in Linguistics, North Sumatera University/USU, Medan, Indonesia \\ ${ }^{4}$ Faculty of Cultural Studies, English Department, North Sumatera University/USU, Medan, Indonesia \\ ${ }^{5}$ Faculty of Indonesia Language Department, State University of Medan/Unimed, Medan, Indonesia

\section{Email address:} \\ bukharyahmedal@gmail.com (M. Ridwan), ahmedalbukhary@yahoo.com (S. Daulay)
}

\section{To cite this article:}

Syahnan Daulay, Amrin Saragih, Tengku Silvana Sinar, Sahron Lubis. Language Choice and Level of Threatened with Extinctionat Siladang Language. International Journal of Language and Linguistics. Vol. 3, No. 6, 2015, pp. 377-382. doi: 10.11648/j.ij11.20150306.20

\begin{abstract}
Siladang language transmission has some barries in intergenerational experience because of the constraints of social and psychological problem. The use of Siladang language in the realm of the family and neighbours at the region of Siladang becomes narrow as a result of the dominance of Mandailing language. Siladang language is no longer as the primary tools of communication. Now it is being replaced by the Mandailing language. There is a tendency of Siladang community to leave the language and switch to Mandailing language in the realm of public communication that presents a different tribe, that is the tribal interlocutors of Mandailaing. Siladang language gets a pressure from Mandailing language in Siladang region. As a result, the durability of the Siladang language begins to decline and fragile. Now, the rate of extinction of it is at the worrying scale based on the parameters of Grenobie and Whaley (2006).
\end{abstract}

Keywords: Retention, Shift, Language Choice, Language Shift

\section{Introduction}

Siladang language is categorized as a linguistic minorities. This language is only found in the Sipapaga Village and Aek Banir Village in the District of Panyabungan, Mandailing Natal (Madina), North Sumatra Province. The number of speakers (ethnic populations Siladang) is recorded 2.358 people (Based on The Central of Statistic Bureau, Madina, 2014). It is still functioning as a means of communication for ethnic Siladang inlimited space, time, and ecology because of being pressured by the dominance of the neighbor language, namely Mandailing language.

Ethnic Siladang as a speaker of Siladang languageis a minority ethnic surrounding the majority ethnic that is Mandailing ethnic as a speaker of Mandailing language. Geographically, both of Siladang ethnics are living in the middle of Mandailing ethnics, in the east and southeast and the north and south of the village. Siladang ethnic ancestors are Lubu. Historically, ethnic Siladang are migrants from Pinyongek (Sibinail), an area located in the village of Muara Sipongi, Madina, North Sumatra province, which is border directly with the province of West Sumatra. But there is not an accurate and factual information related to the migration of ethnic Lubu (Siladang) of Pinyonek to the District of Panyabungan which is now known as the Sipapaga Village and Aek Banir Village.

Based on the observations, the progress of Siladang ethnic is far behind Mandailing ethnic in the sociocultural aspects, such as agriculture, trade, and in the field of language in cultural activities, such as marriage, religion associations, and so on. In the region of Siladang (Sipapaga and AekBanir), Mandailing language seemshaving a broader communication function than Siladang language. Theevidence can be seen when there is a communication between Siladang and Mandailing people, they use Mandailing language as a way of communication. When Siladang people live in Madailing region, they also use Mandailing languge as a tool of interaction. The choice of language is precisely the dominant society that is Mandailing language as the national as a way of communication or as a lingua franca across-Mandailing ethnic Siladang. The context and situation of language selection occured is something 
unique, because they choose Mandailing language as a communication, not Indonesia language, as it is common used in many regions or areas of Indonesia as a inter-ethnic unity interaction.

What does the causeof Siladang people choose Mandailing language as a means of communication across ethnic, even among them have the same ethnic? There are several factors suspected by Siladang people use Mandailing language as a way of interaction by exploring research. First, the transformation of Siladang language is allegedly not passed to the young generation, or in other word there is a intergenerational obstacles. Secondly, it could be not only as a first language (mother tangue) obtained Siladang society since childhood or from proficient. Third, it could be the competence or mastery of Siladang language by Siladang community begins to decline due to the dominance of the use of Mandailing language or even it is associated with the attitude of not confident using the Siladang language. Another factor that may also be a cause is a representation of a negative attitude towards the ethnic of Siladang. So they tend to hide their identity by means of ethnicity.

The fact is that in a society with diverse language use, there will be a choice of languages (language choice). That is, the choice of language in a bilingual society is the fact that the world community. Grosjean (1982: vii) estimates that about half the world's population is bilingual. In the bilingual community or multilingual there are two patterns of language use that relationship can be observed, namely the language maintenance and language shift. The consequences of the use of language with all the supporting factors led to a language to survive and thrive, while disloyalty towards language speakers so switching to another language led to a shift in the language. Language shift can also cause these languages become extinct or endangered. A language can survive if it remains a process of continuous transmission from one generation to the next (Fasold, 1992: 181; Sumarsono, 1991: 178). Thus, to survive or not a language is determined by factors of regeneration of its speakers.

One component of substantial regeneration efforts of speakers are a community of children and adolescents (young generation). The continuity of a language in a social ecology can be observed from the domain of language used (domain of language use) by community of young people in their social environment. In a period of socio-psychological susceptible to change, the young generation is the main indicator to see the process of intergenerational language. There are 3 domains of observations which isstrongly associated with social and ecological environment speakers, namely the realm of families, neighborhoods, and closeness. To view the transmission process, it is necessary to observe the language used to each interlocutor. The language used to each interlocutor in all three domains is crucial patterns and direction of maintenance or language shift in society.

This article comes from the results of a study of options in the realm of language families, neighborhoods, and closeness that occurs in the community of speakers of Siladang language. Community speakers of it, is referred to in this paper are ethnic of Siladang, one of the ethnic minorities in Indonesia, which is District of Mandailing Natal, North Sumatra Province.

\section{Theoretical Review}

\subsection{Language Death}

The maintenance and revitalization of the language is often associated with the condition of the strength or durability of language faces pressure from outside and from within the language itself. Strong pressure and continuously against the other languages, both of which come from outside or from within a language, it can cause the power of language to survive becoming weaker. When the strength or durability of language has weakened, in turn, that language will be marginalized and result will be language change), language shift and the death of a language (language death).

Deaths language (language death) occurs when there is no longer a native speaker of the language. This can happen because all of the speakers were dead because of natural disasters (the case of Tambora on Sumbawa language), or due to naturally, last speaker was dead because of age. The term language of death is often used in the context of the loss of language (language loss) or shift to another language speakers (language shift). Language death is the end point of a process, which is usually preceded by contacts language (language contact) that conditioned the change or transition language. The process, according to Fasold (1992: 213), generallyis slowly and gradually over a relatively long period (gradual) on the situation of diglossia toward a more prestigious language.

\subsection{Language Maintenance, Language Shift, and Endangered Language}

The phenomenon of selection language (language choice) by bilingual occurs in situations of bilingualism. One consequence of the selection of the language is the language usage patterns. Steady pattern of language use causes retention of language (language maintenance), while the faltering pattern among members of the community led to a shift in the language (language shift). Language maintenance and language shift occurs in the long term and is collective. A form of maintenance of the language can be seen from the fact that the language is still used and is selected in the domains of language use by the speakers. Romine (1995) describes the main indicator as a marker retention or language shift is the realm (domain) use of language (language in use). Therefore, there are ten important factors in the language maintenance and study of language shift. These factors are: (1) the strength quantitatively between majority and minority groups; (2) social class; (3) religious and educational background; (4) patterns of settlement / community; (5) loyalty to the homeland or birthplace; (6) the degree of similarity between the language of the majority and minority; (7) extensive intermarriage; (8) the attitude of the majority and the 
minority; (9) the government's policy towards supervision and education of minority languages; and (10) the patterns of language use.

But as long as there are speakers, a language is always changing. The changes of the languageis nature and can not be prevented. The most important thing to be avoided is if the change of a language is negative and leads to the death of it. Changes in negative to the language leads to the death of language which is already happening in some minority languages in Indonesia. One of the potentially endangered language is the Siladang language (BS) contained in Mandailing Natal, North Sumatra. Therefore, language is always changing, which is expected is a positive sustainable change and stable. The language is still used by the speakers and continue to be inherited to the next generation in a sustainable manner. That is, the language survives dynamically though the subsystem is changed such as lexicon, sound, and certain constructions, but not to eliminate it. Certainly the concept of maintanance of language refers its condition would guarantee the existancy of that language in a certain area.

Actually, language exists only in the mind of the its speaker, and will function when the speakers speak each other naturally in their social and natural environment. But language can not be overhauled so alone, or treated carelessly to increase efficiency (Haugen, 1972: 326). The vitality of a language can be seen from the function and the intensity of the use of language by its speakers. The more functions and the higher intensity of the use of language in various domains, the stronger the resistance of these languages from extinction. However, how we can identify languages that are endangered is not always clear. Factors such as the size of the population (Grimes, 1995), bilingualism, urbanization, modernization, migration, industrialization, the function of each language in a society, and the attitudes of the speakers (Fishman, 1972: 213), has a variety of different effects of the various language groups. These factors interact in a dynamic society. According to Dressler (1992: 196), the extinction of a language is usually understood by two presuppositions, namely (1) bilingualism or multilingualism, and (2) a shift in language by the pressure of the dominant language. Language shift includes gradual transition (to the realm of the use) of unstable bilingual until it becomes multilingual, and as a result of this transition is the extinction or death of a language.

Associated with endangered language, Wurm (in Crystal, 2000: 20) argues that there are five criteria: (1) the language is potentially threatened, namely the social and economic language is not profitable, under heavy pressure from the language of the larger, and the early loss of speakers of children; (2) language is threatened, ie little or no more children who learn the language, and the youngest speakers who master the fine is speaking young adults; (3) the language seriously threatened, the youngest speakers who master the language well is speaking to adults aged 50 years or more; (4) language is almost extinct, that only a handful of speakers who master the language well, mostly very old; and
(5) the language destroyed, that there is no such language speakers living.

In addition to the criteria mentioned above, UNESCO (2003) in Saragih (2010) also revealed that there are nine factors to determine the durability or strength discussed, namely (1) intergenerational language transmission, a large number of speakers; (2) comparative speaker with a population; (3) the trend in the realm of language usage; (4) responsiveness to new domains and media; (5) materials for language education and literacy; (6) the language policy by government and institutions, (7) the official status and use; (8) community attitudes towards speakers of their language; and (9) the amount and quality of the document language.

\subsection{The Domain of Language Use}

The use of language in the speech community can be tested by applying the theory of domains (domain). Fishman (1972: 442) defines "domains" as an abstract description of the topic socio cultural communication, relationship among comunicators, and the occurrence of communication in accordance with the social structure of a community. Specific social factors, such as who is speaking, the social context of the conversation, the function and the topic of conversation, is very important in consideration to choose the language in a variety of different types of speech communities. This evidence is very useful, especially when explaining the choice of language that occurs in large community, taking into account the typical interactions involving this factor. We can imagine, for example, a "typical" family interaction. The locus of the home, the participants are members of the family, and the topic is family activities. A number of typical interaction as it is relevant in deciphering the patterns select code (select language) in the speech community. Such an event is known as the domain of language use (domains of language use). A typical domain involves interaction among typical participants in a typical setting or topic (Holmes, 2000: 22).

Domain is a general concept that is very clearly supported by three important social factor in the choice of language, namely the participants, the background (setting), and topics. This will give a general overview of the various speech community. Information about the doamin used by the community illustrates a very simple model of the norms of the language used in a certain community (Holmes, 2000: 23). Number of domains in a society can not be determined with certainty (Sumarsono, 1993: 14). The concept of the developed domain, in the field of sociolinguistics, refers to a group of institutionalized social situations which are usually limited by a series of rules of conduct together (Crystal, 2000). In multilingual communities, the variety of topics and choice of language used by participants is the dependent variable of the different domain in the communities to be studied. Domains are often mentioned such as home, school, workplace, as well as cultural events and social events. Moreover, it has been shown that the choice of language is a sign of solidarity and group identity. Thus, the explanation to the 
problem of language options, according to the number of domains that the choice was found, considered a strong indicator of the vitality of language.

\section{Location of the Research}

The research is conducted in the village of Aek Banir and Sipapaga, Districtof Panyabungan, Mandailing Natal, North Sumatra Province. The study involves 60 respondents fromSiladang speakers as the study sample. The respondents are divided into two groups, namely respondents which aged 15 to 20 years and groups of respondents aged over 25 years. Respondents from the village AekBanir (30) and Sipapaga (30) are assigned proportionally. They are chosen as respondents which are all ethnicof Siladang who use Siladang language. Selection of teenage respondents as the sample is based on the reason for adolescentswhich is a potential heir to theSiladang language and the adult generation is the generation that will soon pass the language to the young generation as the next heir.

Data of this study is the recognition of the self (self-report) respondents which are captured through questionnaires (questionnaire). This questionnaire contains a list of questions / statements about the respondents' choice of language in the domain of families, neighborhoods, and closeness when communicating with various interlocutors. Choice answers provided on the instrument of the questionnaire is (A) always Siladang language, (B) more often Siladang language, (C) as often Siladang language and Mandailing language, (D) more often Mandailing language, (E) always Mandailing language, and (F) other languages. Data from the questionnaire owns the main data (premier) and analyzed quantitatively by using percentages. In addition to collecting data using questionnaires instrument, the data are also obtained through interviews and direct observation of the behavior of the respondents in the Englishlanguage domains are observed. The data obtained through interviews and observation used to support the main data and analyzed qualitatively. Language selection respondents are also seen connectedness with the variable domain of families, neighborhoods, intimacy, and communication as well as the location of the respondent linguistic environment through cross technique (crosstabulation).

\section{Discussion}

Siladang language (SL) and Mandailing language (ML) are two languages used by speakers to be considered. The youth and adults community in the region of Siladang will be observed. The second language certainly has a different function and position. But in the context of this study, the intensity of the use of language in the domains of language use will clarify the presence of SL in adolescents and adults ethnic communities of Siladang. The results shows the tendency of the use of different languages in different interlocutors in one realm (domain). Therefore, to use the language of the statement of interlocutors, there are some respondents who did not answer. The results of the research on patterns of language use in three domains of observation (the domain of the family, neighborhoods, and intimacy) with different interlocutors can be described as follows.

\subsection{The use of SL in the Family}

The use of language in the family restricted to the home location and their family members with any communications activity. Family members make up of parents, children and siblings. Parents in question is the father and mother of the respondents. Brother surrounds siblings, cousins, uncles / aunts and grandfather / grandmother. With the position of the respondent as a child, then the interlocutors involved in the interaction communication realm of family is father and mother, siblings, uncles / aunts, grandfather / grandmother, and cousins. Similarly, the position of the respondents as the elderly, the interlocutors involved is a child, siblings, uncle / aunt, grandfather / grandmother, and cousins. Communication topics related to family life, about the stuff in the house, relatives, neighbors, and so on.

Results of data analysis describes the different communicative response to the different interlocutors. Communicative response that can be seen from the percentage choice of the language used. In general, adolescent respondents admitted as often SL and ML are used when the communication to the mother and father. The tendency can be seen from the level of the same percentage of frequent between SL and ML (58.7\%) as the highest percentage, the choice is always SL highest ranks, second is $(25.5 \%)$, and the choice is more often ML $(15.8 \%)$ as an option on the order the last of the five options available languages. The phenomenon of the dominance of the frequent use of the same option $\mathrm{SL}$ and $\mathrm{ML}$ in communication also happens to interlocutors siblings $(53.5 \%)$, the interlocutor uncle and aunt $(48.8 \%)$, the interlocutor biological grandparents $(55.2 \%)$, and the interlocutor brother cousins $(46.3 \%)$. The lowest percentage of language options for each interlocutor is more ML, namely to interlocutor siblings (5.5\%), uncle and aunt (4.2\%), grandparents $(2.5 \%)$, and cousins $(5,7 \%)$.

In the adult respondents tendency of language options in the realm of the family when communicating with the interlocutor child is still too dominant on the same option frequently SL and ML with the highest percentage (48.7\%), followed by a choice of more frequent SL (36.2\%), and more often ML (15.1\%). The tendency of domination of the frequent use of the same option SL and ML occurs also during adult respondents communicate with interlocutors cousins (34\%) and siblings (52.2\%). However, adult respondents still maintain dominance usage with the option always SL when communicating with the interlocutor grandfather / grandmother (51.2\%) and uncle/aunt (48\%).

In general, exposure above data illustrate that SL is no longer the primary choice of respondents in communication with various interlocutors in the domain of the family. SL and ML's role seems relatively have equality in the selection 
of respondents in Siladang community, especially the adolescent respondents. These findings once hinted that SL began shifting its role as a means of communication in the family domain of Siladang community.

\subsection{The use of SL on the Neighborhood}

The domainof neighborhood is the second domain after families provide linguistic patterns to respondents. Restricted to locations on either side of the house, gathering places such as cafes, porch or yard, and so on. Topics discussed related to the activities of everyday life, issues of interest, strange happenings and so on. Associated with the location and topic, the interlocutor is limited to the interaction of tribesmen peer communication to friends, friends that tribal younger, the older tribe, and people of different tribes.

The results showed that the tribesmen of peer friends, the choice of language usage between SL and ML average dipped from the highest percentage as often SL and ML $(42.6 \%)$ to more ML lowest percentage $(6.2 \%)$. The highest percentage for each option SL and ML's frequent interlocutor friend tribesmen of peer occur at any location (stall, porch or yard, and so on). The same phenomenon also happens to interlocutors younger tribesmen friend. However, the percentage of choice as frequently SL and ML (49.6\%) and more ML $(13 \%)$ is higher than the language selection to the interlocutor friend tribesmen of the same age. This data illustrates that the intensity of the use of BS diminishing the younger generation. In addition, the choice of languages for the interlocutor of the older tribesmen, the image intensity of the use of language shows a tendency towards the use of a balance between choice as frequently SL and ML (36.4\%) and a lot more options SL (34.5\%) to all locations. Sequence option is always ML lowest (2.5\%). Similarly, the choice of language in the realm of neighborhood for interlocutors who are older tribesmen always balanced percentage between SL choice (13.6\%) and more ML (13\%).

Speakers Siladang teens, when communicating to the different interlocutors tribe (tribe Mandailaing), the intensity of the use of ML by respondents look very dominant. Respondents generally choose more options ML (78.6\%). Data staggering is no respondents chose the option is always SL or more SL when communicating with the different interlocutors with their tribes, especially the tribal interlocutors Mandailaing. For teenagers, speakersof Siladang, ML is regarded as more prestigious language option compared with Siladang language when communicating with people of different tribes.

Adult speakers of the language choice Siladang also showed dominance using $\mathrm{M} \mathrm{L}$ when communicating with interlocutors who are not tribesmen. Siladang for adult speakers, choose more often using ML when communicates with the interlocutor that tribal people constitute the highest percentage of $48.2 \%$, followed by equally frequent choice of SL and ML (29.3\%), always use ML (21\%) and choosing more frequently SL (1.1\%) as the lowest option.

ML use options ismore dominant by youth and adult respondents to the different interlocutors seem to reinforce the fact that parts of Siladang ethnic tolerance. That is, the tolerance is not only manifested in social behavior, but also in language behavior. Embodiment in language behavior is to not force themselves to use their ethnic language (SL), but using language commonly understood (ML) which regarded them as the language is more neutral and more prestigious. However, the choice of such language is not necessarily meant as a tolerant attitude towards other ethnic Siladang tribes around him.

\subsection{The Use of SL on Close Relationship}

The domain of intimacy is meantthe fabric of a close relationship among members in a speech community. Relationship closeness to the community of youth and adults is characterized by the presence of a special rapport and very familiar among participants. Repertoire of verbal communication that occurs in the interaction may be personal, confidential, relaxed, joking, vulgar, silly, and so on. Communication topics related to events and matters relating to parents, friends, the opposite sex, hobbies, games, entertainment, and interesting issues. Communication interactions in the realm of intimacy is not limited by location. That is, the location could be in the home of each participant, at school, in shops, on the home page, in the river when bathing, in the garden, and in other places. Interlocutor in the realm of intimacy are just close friends. Therefore, a close friend is limited to close friends and a close friend of a different tribe.

The results showed that the percentage of respondents of teen choice of language used to close friends tribesmenis quite varied. The highest percentage remains the same option frequently SL and ML (35\%). Furthermore, the average percentage dipped to SL choice more often (25.1\%), always SL $(21.1 \%)$, more often ML (17.7\%), and always ML $(11.1 \%)$. What's interesting about this data is the consistency percentage remains high language option on the range of choices as often SL and ML.Language options of adult respondents did not seem much different from the respondents teens when communicating with close friends that tribal interlocutors in the realm of intimacy.

\section{Conclusion}

Shifting choice of language is a reality experienced by the community of Siladang. The use of SL in the domain of the family, neighborhoods and community closeness of Siladangis no longer be the first choice due to start competing with the use of ML. This fact is revealed by the choice of language used in Siladang community to interact verbally to various interlocutors in the realm of families, neighborhoods, and closeness. The third fundamental sphere in BS preservation efforts have begun to be dominated by the use of ML, thus shifting the function and position of SL for the community On the one hand, the decrease in the intensity of use of SL and on the other hand the use of ML intensity is increased.

SL intergenerational transmission (adults to adolescents) is encountered resistance thereby perpetuating the language 
behavior of Siladang communities which no longer gives priority to the identity of ethnicity but rather tend to "disguise" when communicates in a public space in the area of Siladang. Behavioral conditions such Siladang speaking communityis increasingly encourages accelerated extinction of SL. Because the rate of the death of the language is currently on a scale of 2 : languages at risk of extinction and scale 3: start endangered languages, as well as moves lead to the scale 4: severe conditions because the language is slowly becoming obsolete speakers.

\section{References}

[1] Fasold, Ralph W. 1985. The Sociolinguistics of Society. Oxford: Blackwell.

[2] Fasold, Ralph W. 1993. The Sociolinguistics of Language. Oxford: Blackwell.

[3] Fishman, Joshua A. 1972. The Sociology of Language. Rowley. Massachussetts: Newbury House.

[4] Fishman, Joshua A. 2001. Current Issues in Language Planning. Paris: Mouton.

[5] Grosjean, Praancois. 1982. Life with Two Languages: An Introduction to Bilingualism. New York President an Fellows of Harvard College.

[6] Bonvillain, Nancy. 2003. Language, Culture, and Communication: The Meaning of Messages (Fourth Edition). New Jersey: Prentice Hall.
[7] Butar-Butar, Maruli, dkk. 1984. Morfologidan Sintaksis Bahasa Siladang. Pusat Pembinaandan Pengembangan Bahasa.

[8] Chambers, J K. 2003. Sociolinguistic Theory (Second Edition). Oxford: Blackwell.

[9] Crystal, David. 2000. Language Death. Cambridge: Cambridge University Press.

[10] Dressler. 1992. Language Death. Oxford: Blackwell.

[11] Fasold, Ralph W. 1985. The Sociolinguistics of Society. Oxford: Blackwell.

[12] Fasold, Ralph W. 1993. The Sociolinguistics of Language. Oxford: Blackwell.

[13] Haugen, E. 1972. Bilingualism in Americas: A Bibliography and Research Guide. American Dialect Society.

[14] Holmes, Janet. 2001. An Introduction to Sociolinguistics (Second Edition). Edinburgh: Pearson Education Limited.

[15] Romaine, Suzanne. 1995. Bilingualism (Second Edition). Oxford: Blackwell.

[16] Sarfina, T. dan T. Silvana Sinar. 2009. "Prosidi Bahasa Siladang Sumatera Utara" Makalah Kongres MLI (KIMLI) 2009. Batu Malang Indonesia.

[17] Saragih, Amrin. 2010. "Revitalisasi Bahasa Daerah". Artikelpada Harian Waspada 21 Februari 2010.

[18] Sumarsono. 1993. Pemertahanan Bahasa MelayuLoloan di Bali. Jakarta: Pusat Pembinaandan Pengembangan Ba. 